\title{
State Supervision of Local Assessments
}

\author{
By Frank B. Jess \\ President, New Jersey State Board of Taxes and Assessment
}

\begin{abstract}
CoverNoR EDWARDS of New Jersey, in his recent message to the legislature under the heading "Taxation," strongly recommended that the powers of the State Board of Taxes and Assessment be enlarged as one means of securing a more equal distribution of the tax burden. He said:

The practical problem of taxation now confronting us, is the problem of so making our tax levies that all property subject to taxation shall contribute to the support of government precisely in proportion to the value of such property. The accomplishment of this object would, in my judgment, be materially advanced by widening the powers of the State Board of Taxes and Assessment.
\end{abstract}

He then urged that the power of reassessment be definitely vested in the State Board, and added:

The State Board should also be given such powers as will enable it to enforce any order or direction issued to a local assessor. The local assessor is the agent of the state in performing a highly important public duty, and the state should devise the means to make sure that that duty is honestly and efficiently discharged.

The recommendation made by Governor Edwards for improving the assessing machinery of New Jersey is equally apropriate to any other state in which the general property tax is relied on as the chief source of public revenue, and part of the levy is for state uses.

Some of the most serious defects in the administration of state taxing systems are due to the lack of authoritative supervision and control. While the cost of government has increased tremendously, and many new sources of revenue have had to be found, very little progress has been made in the direction of improving the processes by which taxes are levied. The problem of raising by taxation the vast amounts of money required for public purposes has become year by year more intricate and perplexing, but one of the principal factors in the right solution of that problem has been persistently ignored. I refer to the primary assessment. This is the foundation that supports every system of taxation. In the scheme of the general property tax, by which the great bulk of the revenues are raised for municipal expenditure, the initial valuation determines whether the tax burden shall be equally distributed. Recognizing the fallibility of the assessor, legislators have wisely provided methods for the review and correction of his work.

But little has been done to solve the problem at its source. Schemes for alteration, revision and equalization are proper and necessary, but in the nature of things they can remedy only a small percentage of the inequities and injustices which result from defective valuations. When the assessor by his act decides what proportion of a taxpayer's property shall be taken for public use his decision is, in ninetynine cases out of a hundred, final and conclusive. The power he thus possesses constitutes him one of the most important agents in our political system. He should be selected with special reference to his integrity and his expert qualifications for the work he is to do.

As a rule those considerations have no bearing whatever upon his selection. There are exceptions to this rule, but it may be asserted as a general prop- 
osition that ability to appraise property accurately is not the controlling principle in the choice of assessors. They are either elected or appointed. Whichever method of selection is used, political considerations enter much more largely into the choice than regard for efficiency. In most cases regard for efficiency is a minus quantity. Much might be said on this subject of selecting assessors, but the aim of this discussion is not to point out how it might be possible to improve the quality of assessment by improving the method of choosing assessors. The purpose is rather to suggest how better assessments may be obtained by building upon the assessing structure as it already exists.

Two things are necessary to attain this result. In the first place the public must awaken to the fact that the assessment of property for taxation is the function of government that most vitally affects the owners of the property taxed. Secondly, such machinery will have to be set up as is necessary to the efficient performance of that function. It is unlikely that this will be done until the first conditjon has been realized. Legislators seldom move in advance of public sentiment. It is only by discussion and agitation that public opinion can be crystallized and induced to express itself effectively. The suggestions here made are intended to contribute to that discussion in a constructive way.

The local assessor should be subservient to state control exercised by a state agency. That state agency should be a board, or commission, appointed by the governor, with adequate powers and effective means to enforce them. These powers should include authority:

(a) to establish standards of valuation and to compel the observance of those standards. (b) to make rules and issue orders binding upon the assessor.

(c) to order or make a reassessment of any property, or all of the property in any taxing district, or in any county.

(d) to remove, or institute proceedings for the removal of, any assessor for failure in the performance of duty.

(e) to prescribe forms and rules, and compel their use, for the return of property by taxpayers.

(f) to prescribe penalties for failure to comply with its rules and orders.

(g) to review assessments on appeal and to render judgments not subject to judicial reversal except upon questions of law.

It may be objected that the powers here proposed to be vested in a state board are drastic and far-reaching. The answer to that objection is that unless such a board is clothed with such powers the purpose of its creation can not be accomplished. It must be borne in mind that the proposal contemplates a body capable of achieving a fair and equitable assessment throughout the state.

It may be further objected that to endow a state board with such autocratic powers would deprive municipal units of some of their authority within their own jurisdiction. The answer to that objection is, first, that the right to levy taxes is one which inheres in the sovereignty of the state, and can be exercised only in the way and within the limits which the state may prescribe, and second, that the state as a whole is concerned with each individual assessment. The valuation of property in each taxing district is a matter of general, as well as local, interest. That valuation is the basis not only of what the property in that particular district shall pay in taxes, but also is an element in determining what property in other districts shall pay. The assessor, while locally selected to act in a given municipality, is the agent of the state and should be subservient to 
the state in the performance of his function. These are some of the legal aspects of the situation. The practical considerations are equally pertinent.

It is obvious that if all the taxable property in the state should be assessed at its true value, or at a uniform percentage of true value, the burden of taxation would be apportioned with exact equality. The chief objective of the assessing system of the state should, therefore, be uniformity of valuation. It would be foolish to suppose that this ideal can ever be wholly attained. But it is more foolish not to aim at its attainment. The scheme of assessment should be devised with that end in view and so framed as to facilitate its achievement. The prevailing scheme provides as many assessors as there are taxing units. Even if each assessor were an expert, the grand result inevitably would be a great variety of valuations. As so many assessors are not experts the absence of uniformity is all the more conspicuous. Each assessor or assessing body is now a separate machine, functioning independently in a particular territory. He should be a part of a system having a central power plant functioning for the entire state. In other words, the assessing authority should be lodged in a state board and be exercised directly through the local assessor. I do not wish to be understood as suggesting that state boards are omniscient, or that they always are composed exclusively of men who are free from human frailties and limitations. I am, for the moment, leaving the matter of personnel out of consideration. The point I wish to make is that, since the assessment of property is a state function, and since all the people of the state are affected by all the assessments, the state should set up its own immediate agency to see that all assessments are on a parity. This is a tremendous task.

It may be conceded that in many taxing districts, and especially in some of the larger cities, the work of assessment is exceedingly well done. In such cases, state supervision would not hinder but rather fortify efficient local administration. The chief result of strict state control would be to establish and maintain in all taxing districts the high standards which now exist in some of them.

Any general plan of state supervision must, of course, be subject to such modifications and adjustments in detail as might be necessary to adapt it to the varying needs and peculiar polity of a particular state. All that is here contended for is the application of the fundamental principle that the base of the general property tax shall be designed and built to meet the requirements of the superstructure which it supports. The suggestion is simply that the state, under whose authority taxes are levied, shall through its own direct agency, vested with plenary powers, see to it that such taxes are levied upon a uniform basis of valuation. 